\title{
Compositional and fatty acid analysis of Kankrej cows' milk
}

\author{
PC Joshi ${ }^{1}$, MM Pawar ${ }^{1}$, SS Patil ${ }^{1}$, HH Panchasara ${ }^{2}$ and JP Gupta ${ }^{3}$
}

Received: 22 May 2020 / Accepted: 28 June 2020 / Published online: 27 October 2020

(C) Indian Dairy Association (India) 2020

\begin{abstract}
A study was conducted to assess the composition and fatty acid profile of milk obtained from Kankrej Cows. Milk samples from twenty Kankrej cows (average 60 days in milk; 9.5 $\mathrm{kg} / \mathrm{d}$ of milk yield and $355 \mathrm{~kg}$ of body weight) were collected to determine milk composition and fatty acid profile. Mean milk fat, solids not fat, protein and lactose were $4.15,8.55,3.40$ and $4.48 \%$, respectively. In Kankrej cow milk saturated fatty acids (SFA) accounted for $73.17 \%$ and unsaturated fatty acids (UFA) accounted for $26.83 \%$ of total fatty acids. In UFA, concentration monounsaturated fatty acids (MUFA) was $22.94 \%$ and polyunsaturated fatty acids (PUFA) was $3.89 \%$. The ratio UFA/ SFA was 0.37 which ranged from value 0.28 to 0.47 . Among the SFA, palmitic acid $(\mathrm{C} 16: 0 ; 31.22 \%)$ was present in the highest level followed by stearic acid $(\mathrm{C} 18: 0 ; 16.02 \%)$ and myristic acid (C14:0; 13.45\%). Oleic acid (C18:1) was ranged between 13.43 to $25.31 \%$. The average value for $\mathrm{C} 4: 0$ and $\mathrm{C} 6: 0$ were 2.07 and $1.84 \%$, respectively. Linoleic acid (C18:2) and linolenic acid (C18:3) were ranged between 1.12 to $5.42 \%$ and 0.65 to $2.18 \%$, respectively. Results indicated that milk composition and fatty acid profile of Kankrej cow are comparable to other Indigenous breeds.
\end{abstract}

Keywords: Fatty acid profile, Kankrej cow, Milk composition

College of Veterinary Science and Animal Husbandry, Sardarkrushinagar Dantiwada Agricultural University, Sardarkrushinagar, Gujarat

\author{
${ }^{1}$ Department of Animal Nutrition \\ ${ }^{2}$ Livestock Research Station \\ ${ }^{3}$ Department of Animal Genetics and Breeding
}

JP Gupta $(\bowtie)$

Department of Animal Genetics and Breeding, College of Veterinary Science and Animal Husbandry, Sardarkrushinagar Dantiwada Agricultural University, Sardarkrushinagar, Gujarat

Email: jp.prakash01@gmail.com
India is the largest producer of milk in the world with 187.7 million tonnes production in 2018-19 (BAH\&FS, 2018-19). Dairying is an important activity in Indian economy contributing about 27 per cent of the agricultural gross domestic product which is around 4 per cent of the national GDP (Singh et al. 2019). Milk and milk products are the major source of nutrients in the human diet as they are rich source of fat, protein and carbohydrates. Milk fat is also carrier of the naturally present fat-soluble vitamins (A, D, E and $\mathrm{K}$ ) as well as $\beta$-carotene. The main lipids in dairy fat are the triacylglycerides, accounting for more than $98 \%$ of total fat. Triacylglycerides composition is extremely complex as more than 400 different fatty acids are present in milk fat (Hanuš et al. 2018). Milk fat consists of about $70 \%$ of saturated fatty acids (SFA) and $30 \%$ unsaturated fatty acids (UFA). Among UFA, $25 \%$ is monounsaturated fatty acid (MUFA), $2.3 \%$ is polyunsaturated fatty acid (PUFA) and $2.7 \%$ is trans-fatty acid (Meena et al. 2019). The milk fatty acids are preferentially hydrolysed and transferred directly from the intestine to the bloodstream. Afterwards, they are rapidly metabolized in the liver and used as energy source for active cells. They also contribute to the regulation of cell metabolism and play an important role in intracellular signalling (Schönfeld and Wojtczak, 2016). The fatty acid composition of milk fat greatly influences the physico-chemical, functional and nutritive properties of milk. Composition of milk fat varies from species to species, feed consumed by lactating animal and lactation status.

Nowadays, not only the nutritional value of milk but also composition and fatty acid profile of milk have attracted interest of consumers. However, very limited research has been conducted with regards to milk fatty acid profile of Indigenous cows (Saroj et al. 2017). Out of the total 192.49 million cattle population, 142.11 million was contributed by Indigenous cattle with a decline of $6 \%$ in the total indigenous cattle population $\left(20^{\text {th }}\right.$ Livestock Census, 2019). Among the Indigenous cattle, Kankrej is one of the important breeds of cattle in India which is mainly found in the region of north Gujarat and neighboring districts of Rajasthan. Though, Kankrej is dual purpose breed, but also good milk producers (Ekka et al. 2014; Gupta et al. 2019). The average milk yield of Kankrej cattle is around $1,738 \mathrm{~kg}$ with fat content around minimum 2.9 to maximum 4.2\% (NBAGR, 2019). However, Kankrej cows maintained at Livestock Research Station, Sardarkrushinagar 
Dantiwada Agricultural University, Gujarat had average standard (305 days) lactation yield of 2501 litres during the year 2018 (Anonymous, 2019). Knowledge of milk fatty acid composition offers an opportunity to know the concentrations of various fatty acids and bioactive lipids present in milk. To the best of our knowledge only one study (Bharwade et al. 2017) has reported the fatty acid profile of Kankrej cow milk. Therefore, this study was planned to evaluate milk fatty acid profile of Kankrej cows.

Milk samples from twenty lactating Kankrej cows (average 60 days in milk; $9.5 \mathrm{~kg} / \mathrm{d}$ of milk yield, $355 \mathrm{~kg}$ of body weight) were collected during the month of March (2019) from the cows at Livestock Research Station, Sardarkrushinagar Dantiwada Agricultural University, Sardarkrushinagar, Gujarat, India. It is located in semi arid region of north Gujarat having latitude of 24.35 North and longitude of 72.59 East and at an elevation of 189 meters above the mean sea level. All animals were maintained under uniform management conditions and feeding regime. Cows were fed with commercial concentrate, lucerne, maize fodder and jowar hay to meet the nutrient requirement. The feed was offered twice daily in equally divided doses, while clean drinking water was made available $a d$ lib. The chemical composition of feeds and fodder used in this study is given in Table 1.

Analysis of milk fatty acid profile was conducted at ICAR-Central Institute for Research on Goats, Makhdum, India. Fat was separated from each collected sample and was methylated using sodium methylate according to O'Fallon et al. (2007). Fatty acid methyl esters were analyzed using a gas chromatograph (Thermo Scientific Ceres 800 ) with flame ionization detector and capillary column $(60 \mathrm{~m} \times 0.25 \mathrm{~mm} \times 0.20 \mathrm{~mm})$. The initial oven temperature was $120^{\circ} \mathrm{C}$, held for $5 \mathrm{~min}$, subsequently increased to $240^{\circ} \mathrm{C}$ at a rate of $2^{\circ} \mathrm{C} \mathrm{min}-1$, and then held for $60 \mathrm{~min}$. Nitrogen at a flow rate of 1 $\mathrm{ml} / \mathrm{min}$ was used as the carrier gas. Both the injector and the detector were set at $260^{\circ} \mathrm{C}$. The split ratio was $30: 1$. Fatty acids were identified by comparing their retention times with the fatty acid methyl standards and were expressed as percentage of total fatty acids.Milk samples were also analyzed for milk composition (fat, solids not fat, protein and lactose) using EKOMILK Ultra Pro Milk Analyzer (Everest Instruments Pvt. Ltd.). The mean, standard error (SE), minimum and maximum values for individual fatty acid, groups of fatty acids and milk components were estimated using $\mathrm{R}$ ( $\mathrm{R}$ core team, 2019).

The average values for milk fat, solids not fat, protein and lactose were $4.15,8.55,3.40$ and $4.48 \%$, respectively (Table 2 ). In agreement with the current findings, earlier studies reported similar values for milk components in Kankrej cows (Joshi et al. 2018; Gami et al. 2019). Gajbhiye et al. (2019) reported 4.16, 8.86, 3.28 and $4.83 \%$ of fat, solids not fat, protein and lactose in milk of Gir cows. The mean concentration of PUFA linoleic acid (C18:2) and linolenic acid were 2.60 and $1.28 \%$, respectively in Kankrej

Table 1 Chemical composition (\% DM basis) of feeds and fodder

\begin{tabular}{lllll}
\hline Composition & Concentrate & Lucerne & Green maize & Jowar hay \\
\hline Dry matter & 95.55 & 89.73 & 15.64 & 19.92 \\
Crude protein & 18.59 & 2.29 & 6.16 & 18.76 \\
Crude fibre & 6.58 & 37.58 & 27.43 & 22.64 \\
Ether extract & 2.43 & 1.36 & 1.16 & 2.93 \\
Ash & 8.25 & 10.51 & 8.56 & 9.38 \\
NFC & 35.53 & 28.22 & 40.32 & 27.80 \\
NDF & 35.2 & 57.62 & 43.80 & 41.13 \\
ADF & 19.05 & 45.17 & 33.76 & 21.15 \\
\hline
\end{tabular}

NFC: Non-fiber carbohydrate, calculated by equation: NFC $(\%$ of DM $)=100-(\mathrm{CP}+\mathrm{NDF}+\mathrm{EE}+\mathrm{ash})$; NDF: Neutral detergent fiber; ADF: Acid detergent fiber.

Table 2 Milk composition and concentrations of fatty acid groups (\%) in milk of Kankrej cows (n=20)

\begin{tabular}{|c|c|c|c|c|}
\hline Fatty acid group & Mean & SE & Minimum & Maximum \\
\hline \multicolumn{5}{|l|}{ Milk composition $(\%)$} \\
\hline Fat & 4.15 & 0.07 & 3.13 & 5.09 \\
\hline Solids not fat & 8.55 & 0.04 & 7.72 & 8.90 \\
\hline Protein & 3.40 & 0.02 & 3.06 & 3.59 \\
\hline Lactose & 4.48 & 0.02 & 4.03 & 4.68 \\
\hline \multicolumn{5}{|l|}{ Fatty acid groups $(\%)$} \\
\hline Monounsaturated fatty acids (MUFA) & 22.94 & 0.56 & 19.04 & 28.85 \\
\hline Polyunsaturated fatty acids (PUFA) & 3.89 & 0.33 & 2.16 & 6.75 \\
\hline$\underline{\text { UFA/SFA }}$ & 0.37 & 0.01 & 0.28 & 0.47 \\
\hline
\end{tabular}


Table 3 Milk fatty acids profile (\%) of Kankrej cows (n=20)

\begin{tabular}{|c|c|c|c|c|c|}
\hline Fatty acid & Isomer & Mean & $\mathrm{SE}$ & Minimum & Maximum \\
\hline Butyric acid & $\mathrm{C} 4: 0$ & 2.07 & 0.10 & 1.26 & 2.86 \\
\hline Caproic acid & C6:0 & 1.84 & 0.18 & 0.89 & 3.60 \\
\hline Caprylic acid & $\mathrm{C} 8: 0$ & 0.97 & 0.08 & 0.26 & 1.64 \\
\hline Lauric acid & $\mathrm{C} 12: 0$ & 2.00 & 0.17 & 0.60 & 3.40 \\
\hline Myristic acid & C14:0 & 13.45 & 0.37 & 10.92 & 16.65 \\
\hline Pentadecenoic acid & C15:1 & 0.29 & 0.10 & 0.08 & 1.75 \\
\hline Palmitic acid & $\mathrm{C} 16: 0$ & 31.22 & 0.62 & 26.86 & 36.63 \\
\hline Palmitoleic acid & $\mathrm{C} 16: 1$ & 2.35 & 0.22 & 1.01 & 5.17 \\
\hline Heptadecanoic acid & $\mathrm{C} 17: 0$ & 0.64 & 0.05 & 0.22 & 1.32 \\
\hline Heptadecenoic acid & $\mathrm{C} 17: 1$ & 0.43 & 0.09 & 0.14 & 1.53 \\
\hline Linolenic acid & C18:3 & 1.28 & 0.10 & 0.65 & 2.18 \\
\hline Arachidic acid & $\mathrm{C} 20: 0$ & 0.48 & 0.09 & 0.12 & 1.42 \\
\hline Behenic acid & $\mathrm{C} 22: 0$ & 1.92 & 0.21 & 0.95 & 5.53 \\
\hline
\end{tabular}

cow milk. SFA accounted for $73.17 \%$ and UFA accounted for $26.83 \%$ of total fatty acids. In UFA, concentration MUFA was $22.94 \%$ and PUFA was $3.89 \%$ (Table 2 ). The ratio UFA/ SFA were ranged from 0.28 to 0.47 , with average value of 0.37 . Saroj et al. (2017) reported that milk of Sahiwal and crossbred cows contain 61.35 and $67.43 \%$ of SFA, respectively. The SFA in milk fat of African Indigenous cows were ranged from 60.9 to $78.4 \%$ (Myburgh et al. 2012). The SFA contents of 78.4 vs. $74.5 \%$ were reported in milk of Jersey as compared to milk of Mafriwal (Yassir et al. 2009). Kirchnerová and Vršková (2015) reported SFA, UFA and PUFA were 69.34, 30.66 and 3.55\%, respectively in the milk of Simental dairy cows. In cow milk PUFA account for as little as 3\% of all fatty acids (Markiewicz-Kęszycka et al. 2013); however, Frelich (2009) has found more than 4\% of PUFA in Czech Fleckvieh and Holstein cows. Saroj et al. (2017) reported 1.94 and $1.53 \%$ of PUFA in milk of Sahiwal and crossbred cows, respectively. The PUFA in milk fat of African Indigenous cows were ranged from 1.68 to $3.06 \%$, respectively (Myburgh et al. 2012). Discrepancies in milk fatty acid profile of dairy cows among various studies might be due to type of breed, diet and season of the experiment.

Concentration of individual milk fatty acid in Kankrej cows is given in Table 3. Among the SFA, palmitic acid (C16:0; 31.22\%) was present in the highest level followed by stearic acid (C18:0; $16.02 \%)$ and myristic acid (C14:0; 13.45\%). The average value for short chain fatty acids (SCFA) C4:0 and C6:0 were 2.07 and $1.84 \%$, respectively. Oleic acid (C18:1) a MUFA was ranged between 13.43 to $25.31 \%$ with mean value of $19.18 \%$. Linoleic acid (C18:2) was recorded between 1.12 to $5.42 \%$ with mean value of $2.60 \%$ and linolenic acid (C18:3) was ranged from 0.65 to $2.18 \%$ having average of $1.28 \%$. Very long chain fatty acids C20:0 and C22:0 were found to be 0.48 and $1.92 \%$, respectively. In agreement with the present findings, Bharwade et al. (2017) in milk fat of Kankrej cows recorded 33.18 and $10.87 \%$ palmitic acid (C16:0) and myristic acid (C14:0), respectively. Similar values for palmitic acid (C16:0) and myristic acid (C14:0) were reported in milk of Sahiwal and crossbred cows (Saroj et al. 2017). Palmitic acid (16:0) was accounted for approximately $30 \%$ by weight of the total saturated fatty acids. While, oleic acid (18:1) accounting for $23.8 \%$ by weight of the total unsaturated fatty acids (Samková et al. 2018). Also, different studies suggests that monounsaturated fatty acids (MUFA) content of milk fat was is similar in sheep, cow, and goat milk and may range from about $20 \%$ to about $35 \%$. Among the MUFA group, the oleic acid (C18:1) is characterized by the highest content (Krizova et al. 2017; Samková et al. 2018).

\section{Conclusions}

Results indicated that milk composition and fatty acid profile of Kankrej cow are comparable to other Indigenous breeds. Milk fatty acids concentration is depends upon the interrelationship among dietary lipid supply, rumen fermentation, and metabolic changes occurring in liver, blood, and finally in mammary gland. Further studies are required to know the non-genetic factors influencing milk fat composition in cows.

\section{Acknowledgements}

The authors are thankful to the Dean, College of Veterinary Science and Animal Husbandry, SDAU, Sardarkrushinagar, Gujarat, India for providing the funds to carry out this research work. 


\section{References}

$20^{\text {th }}$ Livestock Census (2019) All India Report. Department of Animal Husbandry, Dairying and Fisheries. Government of India

Anonymous (2019) Annual Progress Report (Jan. to Dec. 2018) Research Sub Committee on Animal Production, 15th Meeting held on 2021th February, 2019 at College of Veterinary Science and Animal Husbandry, Sardarkrushinagar Dantiwada Agricultural University Sardarkrushinagar, Gujarat

BAH\&FS (2018-19) All India (Provisional) Annual Estimate of Milk, Egg, Meat \& Wool production 2018-19. Basic Animal Husbandry \& Fisheries Statistics. Ministry of Agriculture, Department of Animal Husbandry, Dairying \& Fisheries, New Delhi, India

Bharwade M, Balakrishnan S, Chaudhary N, Jain AK (2017) Fatty acid profile and physic-chemical characteristics of milk lipids of Kankrej cow. Int J Curr Microbiol Appl Sci 6: 3035-3047

Ekka P, Gupta JP, Pandey DP, Prajapati KB, Patel JB, Shah RR (2014) Genetic analysis of first production and reproduction traits in Kankrej cattle. Indian J Dairy Sci 67: 236-239

Frelich J, Šlachta M, Hanuš O, Špička J, Samková E (2009) Fatty acid composition of cow milk fat produced on low-input mountain farms. Czech J Anim Sci 54: 532-539

Gajbhiye PU, Ahlawat AR, Sharma HA, Parikh SS (2019) Effect of stage, season and parity of lactation on milk composition in Gir cattle. Int J Curr Microbiol Appl Sci 8: 2419-2425

Gami YM, Patel MP, Pawar MM, Chaudhari AB, Rathod BS, Panchasara HH, Patil SS (2019) Production performance, feed efficiency and their correlation in lactating Kankrej cows at organized farm. Indian J Vet Sci Biotechnol 14: 61-63

Gupta JP, Prajapati BM, Chaudhari JD, Pandey DP, Panchasara HH, Prajapati, KB (2019) Impact of environmental trend in relation to genotypic and phenotypic trend on traits of economic interest in Kankrej cattle. Indian J Anim Sci 89: 1255-1261

Hanuš O, Samková E, Kř́ižová L, Hasoňová L, Kala R (2018) Role of fatty acids in milk fat and the influence of selected factors on their variability - A review. Molecules 23:1636

Joshi PC, Pawar MM, Gami YM, Patil SS, Patel MP, Panchasara HH (2018) A pilot study on effect of feeding castor (Ricinus communis) oil on milk yield and composition in lactating Kankrej cows. J Pharmacogn Phytochem 7: 126-128

Kř́žzvá L, Ryšavý J, Richter M, Veselý A, Hanuš O, Janštová B, Vorlová L, Samková E (2017) Milk yield, milk composition, fatty acid profile and indices of milk fat quality as affected by feeding with extruded full-fat soybean. Mljekarstvo 67: 49-57
Markiewicz-Kęszycka M, Czyżak-Runowska G, Lipińska P, Wójtowski J (2013) Fatty acid profile of milk-a review. Bull Vet Inst Pulawy 57: 135-139

Meena S, Rajput YS, Sharma R, Singh R (2019) Effect of goat and camel milk vis a vis cow milk on cholesterol homeostasis in hypercholesterolemic rats. Small Rumin Res 171: 8-12

Myburgh J, Osthoff G, Hugo A, de Wit M, Nel K, Fourie D (2012) Comparison of the milk composition of free-ranging indigenous African cattle breeds. S Afr J Anim Sci 42(1): 1-14

NBAGR (2019) National Bureau of Animal Genetic Resources. Available at http://14.139.252.116/agris/bridDescription.aspx accessed on 15th December 2019

O'Fallon JV, Busboom JR, Nelson ML, Gaskins CT (2007) A direct method for fatty acid methyl ester (FAME) synthesis: Application to wet meat tissues, oils and feedstuffs. J Anim Sci 85: 1511-21

$\mathrm{R}$ Core Team (2019) R: A language and environment for statisticalcomputing. R Foundation for Statistical Computing, Vienna, Austria.URL https://www.R-project.org/

Samková E, Koubová J, Hasoňová L, Hanuš O, Kala R, Kváč M, Pelikánová T, Špička J (2018) Joint effects of breed, parity, month of lactation, and cow individuality on the milk fatty acids composition. Mljekarstvo 68: 98-107

Saroj B, Tran L, Sharma A, Kumar S, Tyagi A (2017) Seasonal variation in fatty acid profile in the milk of different species under popularly followed feeding system in India. Indian J Anim Sci 87: 484-489

Schönfeld P, Wojtczak L (2016) Short- and medium-chain fatty acids in energy metabolism: The cellular perspective. J Lipid Res 57: 943954

Singh SR, Thakar KP, Soumya, C, Datta, KK (2019) Future of smallholders in the dairy sector: A macro study of Gujarat. Indian J Dairy Sci 72: 534-541

Yassir MA, Arifah AK, Yaakub H, Zuraini A, Zakaria ZA, Somchit MN (2009) Breed effect on fatty acid profile of milk in dairy cows. 21st Scientific Congress of Veterinary Association Malaysia, Aug. 7-9, 2009, Port Dickson, Malaysia pp. 169-171 